\title{
Geographic differences in recruitment and population structure of a temperate reef fish
}

\author{
Phillip S. Levin ${ }^{1, *}$, Wayne Chiasson ${ }^{2}$, John M. Green ${ }^{2}$ \\ ${ }^{1}$ Department of Zoology and Center for Marine Biology, University of New Hampshire, Durham, New Hampshire 03824, USA \\ ${ }^{2}$ Department of Biology, Memorial University of Newfoundland, St. John's, Newfoundland, Canada
}

\begin{abstract}
The purpose of this study. was to assess the importance of pre- and post-settlement processes in the temperate reef fish Tautogolabrus adspersus at multiple spatial scales and in 2 distinct regions, Newfoundland, Canada, and the Gulf of Maine, USA. We examined a total of 20 sites (separated by 100 to $1000 \mathrm{~m}$ ) nested within 10 locations (separated by ca $10 \mathrm{~km}$ ). Greater numbers of adult fish were observed in Newfoundland than in the Gulf of Maine; however, higher abundances of newly recruited fish occurred in the Gulf of Maine. An experiment in which we provided standardized habitats in both regions also revealed that recruitment was higher in the Gulf of Maine than Newfoundland. In the Gulf of Maine, variation in the densities of adults and newly recruited fish was most pronounced among sites, but in Newfoundland we detected pronounced variability at both the site and location scales. Algal height was not associated with among-site variability in the abundances of recruits or adults. Algal coverage, however, was an important predictor of variability of fish abundance in the Gulf of Maine but not in Newfoundland. The age structure of Newfoundland populations suggests that strong recruitment years are rare, while in the Gulf of Maine the age structure is consistent with the expectation of declining abundance with age. Our data suggest that pre-settlement processes are not of primary importance to cunner populations in the Gulf of Maine. Rather, we hypothesize that habitatrelated differences in post-settlement processes are the most significant factors affecting these populations. However, in Newfoundland the evidence gathered thus far supports the hypothesis that episodic settlement is responsible for much of the variation in population size in this region.
\end{abstract}

KEY WORDS: Recruitment - Scale - Habitat structure - Gulf of Maine - Newfoundland - Tautogolabrus adspersus

\section{INTRODUCTION}

Central to our understanding of the ecology of populations and communities is determining what factors or processes limit or generate change in the size of populations. In the past, some workers have suggested that density-independent factors such as fluctuating abiotic conditions were most important in determining population size (Andrewartha \& Birch 1954); others advocated density-dependent biotic processes such as competition (Lack 1954) or predation (Errington 1946) as

\footnotetext{
- Present address: Institute of Marine Sciences, Earth and Marine Sciences Building, University of California, Santa Cruz, Santa Cruz, California 95064, USA.

E-mail: levin@biology.ucsc.edu
}

the predominant processes affecting populations. Unlike many of the species studied historically, most marine species have complex life cycles in which larvae are pelagic and widely dispersed, whereas adults are benthic or demersal and relatively site-attached (Sale 1980, Doherty \& Williams 1988, Roughgarden et al. 1988). Because of their life history, most marine populations, including reef fishes, are considered to be 'open', in which local production of offspring on a scale of meters to kilometers has little to do with recruitment to that same site (Cowen 1985, Roughgarden et al. 1985, Warner \& Chesson 1985, Doherty \& Williams 1988). Such populations have broadened the historical debate on the importance of density dependence versus density independence, and a major challenge presently facing marine ecologists is to distinguish 
between the importance of density-dependent and density-independent processes occurring prior to or after settlement (Underwood \& Denley 1984, Menge \& Sutherland 1987, Doherty 1991, Jones 1991, Robertson 1991, Gaines \& Bertness 1992). In this paper we refer to 'settlement' as the permanent movement of individuals from the water column to the benthos and recruitment' as the numbers of individuals surviving some arbitrary time after settlement (Connell 1985).

Three general models have been advanced to predict how the distribution and abundance of adult fish will vary in time and space. The first of these models asserts that potential settlers are plentiful, and competition for space or food results in density-dependent rates of recruitment. The prediction from this model is that larval settlement and/or early post-settlement mortality is inversely related to the densities of conspecifics (Doherty 1983). A second model termed 'recruitment limitation' asserts that sites are undersaturated with settlers and that upper limits of abundance are set solely by variability in larval supply (Doherty 1981, 1983, Victor 1983). Additionally, a more restrictive interpretation of this model suggests that populations are not only limited by larval supply, but that variation in larval supply causes subsequent variation in population abundance even when some post-settlement density-dependent mortality occurs (Doherty \& Williams 1988). Thus, this model predicts that temporal variation in larval supply is preserved in the age structure of the population and spatial variation in larval supply is reflected in subsequent patterns of abundance in demersal populations (Victor 1986, Doherty 1987. Mapstone \& Fowler 1988, Doherty \& Fowler 1994). A third model argues that predation on new recruits and juveniles can be the predominant process affecting the local dynamics of demersal fish populations. This hypothesis suggests that if predation pressure on individual fish is sufficiently intense, abundances will be low enough that competition for non-refuge resources does not frequently occur (Hixon 1991). If predators are abundant and refuges from predators are limiting, this model predicts that there will be competition for refuges (Hixon \& Beets 1993). However, when settlement is low, density-dependent mortality should not occur.

Although we have presented these 3 models as mutually exclusive alternatives, recent work has emphasized the need to adopt a more pluralistic approach (Warner \& Hughes 1988, Doherty 1991. Hixon 1991, Jones 1991). Single factor explanations are often too simplistic to adequately explain variability in population structure (Strong 1986, Jones 1987, 1990, Forrester 1990, Hixon \& Beets 1993). Several workers have suggested that populations may be both resource and recruitment limited in different locations or at different times (Jones 1984, Roughgarden 1986 , Hixon \& Beets 1989, 1993, Nisbet \& Bence 1989, Carr 1994). For demersal fishes that are site-attached, the relative importance of settlement, resource availability, and predation pressure may differ in patches that are only separated by a few meters. Consequently, over the geographic range of a species, there is no a priori reason to anticipate that the relative importance of various demographic processes should remain constant. Moreover, fluctuations in settlement can influence density-dependent post-settlement processes (Forrester 1990, Jones 1990. Hixon \& Beets 1993).

The relative importance of pre- and post-settlement processes on the abundances of adult fishes is likely to be scale-dependent (Smith 1978, Cowen 1985, Doherty 1991, Williams 1991, Fowler et al. 1992). At large spatial scales (10s to $100 \mathrm{~s}$ of $\mathrm{km}$ ) variation in the delivery of pelagic pre-settlement fish can be affected by oceanographic processes such as current patterns (Cowen 1985). Additionally, mesoscale oceanographic anomalies may produce episodic pulses of settlement and recruitment by delivering pelagic propagules to sites that are at the geographical limits of a species range (Dayton \& Tegner 1984, Cowen 1985). Biotic interactions are generally more important at small spatial scales than at large scales (Antonovics \& Levin 1980, Addicott et al. 1987, Levin 1992). Small-scale interactions between settling fish and resident conspecifics can produce variability in settlement (Sweatman 1985, Booth 1992), and it is only at small scales where the importance of competition (Jones 1986, 1987, 1990, Forrester 1990) or predation (Hixon \& Beets 1993, Carr \& Hixon 1995) have been unequivocally documented for reef fish.

Tests of models that attempt to explain fluctuations in the abundance of demersal fishes have largely been conducted in coral reef habitats, at small spatial scales, and in single geographic locations. The purpose of this study was to examine the significance of recruitment to populations of a temperate reef fish at multiple scales. We first described variability in abundance in space and time of a temperate wrasse, the cunner Tautogolabrus adspersus, at numerous sites in the Gulf of Maine, USA and in Newfoundland, Canada. We then used a correlative approach to distinguish among models attempting to describe the dynamics of fish populations by testing the hypotheses outlined below. In this study we focus on recruitment rather than settlement because (1) the spatial extent of the study prevented the daily sampling necessary to quantify settlement, and (2) previous work has established that settlement and recruitment of the study species are highly correlated at the relevant spatial and temporal scales of this study (Levin 1994a, 1996). Although a correlative approach cannot test for causal mechanisms, it does 
provide insight into the possible processes that may be responsible for the patterns we observed. Specifically, we asked these questions: (1) Does variability in recruitment and adult abundance occur at the same spatial scales in the Gulf of Maine and Newfoundland? (2) Does habitat structure affect recruitment and adult abundance similarly in the Gulf of Maine and Newfoundland? (3) Are large-scale differences in recruitment dynamics reflected in the age structure of cunner populations in the Gulf of Maine and Newfoundland?

\section{STUDY ORGANISM}

Cunner Tautogolabrus adspersus are a common demersal fish and prominent members of nearshore communities in the Northwest Atlantic. Cunner occur from depths of greater than $90 \mathrm{~m}$ (Bigelow \& Schroeder 1953 ) to intertidal zones (Ojeda \& Dearborn 1990) and are common from Newfoundland to New Jersey, USA (Auster 1989). Throughout their range, cunner are associated with reefs, sheltered rock substrata, or manmade structures (e.g. piers, wrecks, etc.). As young, they are often associated with algal cover (Olla et al. 1975, Pottle \& Green 1979, Levin 1991, 1993, 1994b). Cunner have small home ranges (Green 1975, Olla et al. 1975, Pottle \& Green 1979); adults limit most of their activity to core areas averaging $<100 \mathrm{~m}^{2}$ (Pottle \& Green 1979, Bradbury et al. 1995). Tagging experiments have shown that juvenile cunner spend their first year within a few square meters (Tupper \& Boutilier 1995).

Cunner spawn in early and mid-summer (Dew 1976. Pottle \& Green 1979), and their larval life averages 18 to 21 d south of Cape Cod, Massachusetts, USA (Gleason \& Recksiek 1990). Cunner spawn during early July in the Gulf of Maine thus settlement occurs in late summer. In Newfoundland, spawning occurs in late July and early August (Pottle \& Green 1979) followed by settlement 3 to 4 wk later. (J. M. Green pers. obs.j. During their first year, cunner generally reach a length of 25 to $30 \mathrm{~mm}$ total length (Levin 1996), and adult fish can eventually reach a maximum size of $300 \mathrm{~mm}$ (Bigelow \& Schroeder 1953). For the purposes of this study, fish $<30 \mathrm{~mm}$ total length are referred to as 'recruits', and fish $>100 \mathrm{~mm}$ are referred to as 'adults' (Pottle \& Green 1979). We omitted older juvenile fish (30 to $100 \mathrm{~mm}$ total length) from this study.

\section{METHODS}

How do densities of recruits and adults vary between geographic regions? Spatial patterns of abundance for adult and newly recruited cunner were

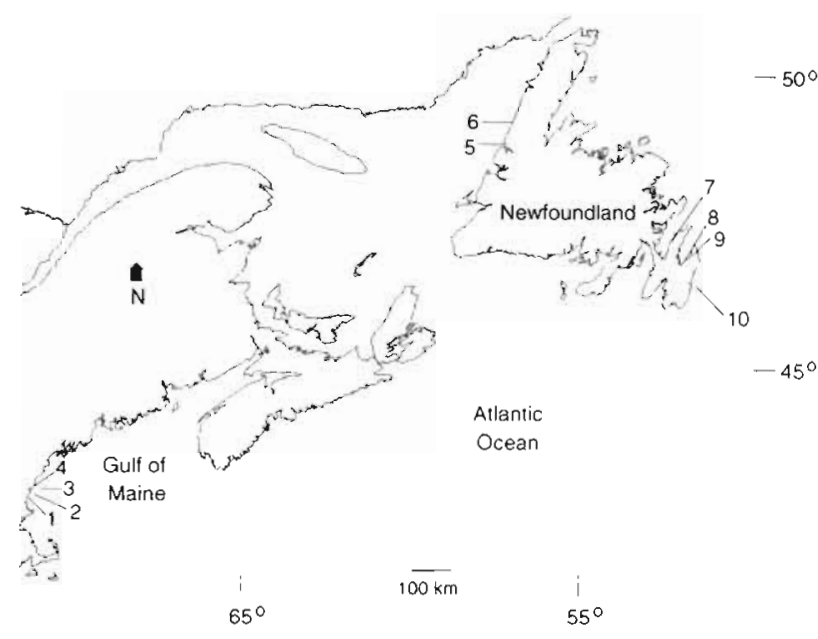

Fig. 1 Positions of 10 study 'locations' are indicated by numbers. Within each location, 2 'sites' were sampled. Location identities are as follows: 1, Portsmouth; 2, Shoals; 3, Boon; 4, Nubble; 5, Bonne Bay; 6, Cowhead; 7. Trinity Bay; 8, Holyrood: 9 , Broadcove; 10, East Coast

examined in 1991 and 1992 at 20 sites, ranging in latitude from $43^{\circ}$ to $50^{\circ} \mathrm{N}$ (Fig. 1). Twelve sites were located in Newfoundland and 8 sites in the central Gulf of Maine more than $1800 \mathrm{~km}$ from Newfoundland. The 2 regions are considered distinct biogeographic provinces (Vermeij 1978), representing Arctic (Newfoundland) and boreal (Gulf of Maine) zones. Sites were selected after extensively surveying numerous areas in both regions, and our study sites appear to be representative of both regions. The spatial extent of this study limited the number of sites that we could adequately sample; therefore, we have studied only a small area in both regions and it is possible that our sites are not representative of entire geographic regions.

Abundances of cunner were estimated by censusing at least 10 haphazardly placed $15 \times 1 \mathrm{~m}$ transects at each site. Because adult and juvenile cunner are less cryptic than recruits, it was necessary to perform separate censuses for these age classes (Lincoln Smith 1988). Thus, at sites with both recruits and adults, a total of 20 transects were censused. Data were analyzed with a 2 -factor analysis of variance (ANOVA) on $\log (x+1)$ transformed data. Both geographic region and year were considered fixed effects.

Because algal biomass and species composition varied between the Gulf of Maine and Newfoundland (see 'Results'), we performed an experiment in which recruitment was monitored to standard habitat units (SHUS) in both the Gulf of Maine and Newfoundland. SHUs consisted of $0.25 \mathrm{~m}^{2}$ of wire mesh $(5 \mathrm{~mm}$ mesh size) attached to a PVC pipe frame. To prevent burial by shifting sand, legs were attached to the SHUs so 
they stood $0.5 \mathrm{~m}$ above the substratum. SHUs were deployed in April 1991 in Gosport Harbor, Isles of Shoals, New Hampshire, and in May 1991 in Broad Cove, Newfoundland (locations 2 and 9 on Fig. 1). As part of another experiment reported elsewhere (Levin 1993, 1994a), SHUs were deployed in 2 spatial configurations: clumped ( 4 individual SHUs adjacent and touching to form a $1 \mathrm{~m}^{2}$ square) and random (4 SHUs placed randomly such that they were separated by 1 to $2 \mathrm{~m}$ ). Twelve replicates of each spatial configuration were deployed in both the Gulf of Maine and Newfoundland. Sets of 4 SHUs were separated from each other and natural habitat by $>6 \mathrm{~m}$. By July, SHUs in both locales were coated with filamentous algae and colonial diatoms, thus providing appropriate habitat for recruiting cunner (Levin 1993).

In the Gulf of Maine, SHUs were visually censused 11 of the 17 days when cunner settlement was observed in 1991 (August 1 to 17) and on 2 more dates following the settlement season (August 28 and October 21). In Newfoundland, we censused SHUs weekly beginning ca 3 wk after the onset of cunner spawning (late July). We increased our sampling to every $2 \mathrm{~d}$ from September 1 to 10 , and then reduced our sampling to weekly thereafter. In both locations, sampling encompassed the entire settlement period.

How do densities of recruits and adults vary between locations within geographic regions and sites within locations? 'Locations' were defined as places separated by greater than $10 \mathrm{~km}$ and 'sites' as places separated by 100 to $1000 \mathrm{~m}$. The size of the site scale was chosen to reflect the home range of adult cunner (Pottle \& Green 1979, Bradbury et al. 1995), and thus we should have been sampling a resident population of fish with minimal migration. Two sites were sampled within each of 4 locations in the Gulf of Maine and 6 locations in Newfoundland. Censuses were conducted in 1991 and 1992 as described above. In 1993 additional censuses were conducted in Newfoundland sites; however, only recruits were enumerated along these transects.

Data were $\log (x+1)$ transformed and analyzed with a 3-factor ANOVA for each geographic region. Year was considered a fixed factor, while location and site (nested within location) were considered random factors. The ability to statistically detect a difference depends on the magnitude of the difference relative to the underlying variability. The magnitude of the difference is the most relevant issue in the context of this study since simply detecting a difference indicates little about whether a difference is biologically 'important', and the failure to detect a statistical difference may reflect low power rather than an 'unimportant' effect. Consequently, in addition to reporting significance values, we also examined the size of differences in the mean density of fish among locations and sites relative to the residual variation. We consider this measure as our operational definition of importance. To estimate the magnitude of difference we adapted the computational procedures for degree of association $\left(\rho_{\mathrm{I}}\right)$ of Dodd \& Schultz (1975) and Winer et al. (1991) for our ANOVA model. For location, $\rho_{\mathrm{l}}$ was estimated as:

Location $\rho_{1}=$

$$
\frac{p \mathrm{MS}_{\text {location }}}{\mathrm{SS}_{\text {total }}+\mathrm{MS}_{\text {location }}+p \mathrm{MS}_{\text {locationxyear }}+p \mathrm{MS}_{\text {stexyear }}-p q \mathrm{MS}_{\text {error }}}
$$

where $\rho_{1}$ is an estimate of the degree of association between the treatment effect (location) and the dependent variable (fish density), $p$ is the number of levels of location, and $q$ is the number of levels of site. For site, $\rho_{\mathrm{I}}$ was estimated as:

$$
\text { Site } \rho_{I}=\frac{q \mathrm{MS}_{\text {site }}}{\left(\begin{array}{c}
\mathrm{SS}_{\text {totai }}+\mathrm{MS}_{\text {site }}-\mathrm{MS}_{\text {error }}+q \mathrm{MS}_{\text {locatonxyear }} \\
+q \mathrm{MS}_{\text {sitexyear }}-p q \mathrm{MS}_{\text {error }}
\end{array}\right)}
$$

How does habitat structure affect variability of recruits and adults? To explore the relationship between habitat structure and the abundance of fish at large spatial scales (among reefs), we first quantified several different attributes of the habitat at sites in Newfoundland and the Gulf of Maine. Because previous work has shown that macrophyte cover (Levin 1991, 1993) and height (Levin 1991) influence smallscale patterns of distribution in juvenile cunner, we focused on these factors in this large-scale study.

For algal analyses, 4, 7, and 11 sites were examined in the Gulf of Maine during 1990, 1991, and 1992, respectively. Twelve sites were examined in Newfoundland in both 1991 and 1992. Algae were grouped as kelps (Laminaria saccharina, L. digitata, and Agarum cribrosum), foliose (Ulva lactuca) and branched (mostly Desmarestia spp., Ahnfeltia plicata, Codium fragile). These groupings have been used in the past (Levin 1991, 1994b), and experiments have demonstrated that cunner recruits do not distinguish between the algal species within these groupings (Levin unpubl. data). The mean percentage cover at each site was estimated by recording the type of plant at $10 \mathrm{~cm}$ intervals along randomly placed $15 \mathrm{~m}$ transects. A minimum of 3 transects was sampled at each site. Average cover of each algal type was calculated for each site and a multiple analysis of covariance (ANCOVA) was used to test for effects of kelp, branched algae and foliose algae on among-site variation in fish abundance in different years. In these models non-significant interaction terms ( $p>0.25)$ were pooled with the error mean square (Underwood 1981). The results of these analyses were visualized by performing regressions of fish density on algal cover in each year. The regression analyses were used only as 
an aid to interpret the multiple ANCOVA and were not used to determine significance; only the ANCOVA was used to ascertain statistical significance.

Average algal height for each site was determined by measuring the height of plants in at least 30 randomly selected positions. Height was considered to be the distance from the substratum to the apex of a plant in its natural position. An ANCOVA was used to test the hypothesis that variation among sites in the average abundance of fish in 1991 and 1992 was explained by the mean height of algae. The mean number of fish censused at a site was considered the response variable with site as a main effect and the mean algal height at that site as the covariate.

Does the age structure of adult populations vary between geographic regions? Adult cunner were collected in September-October 1992 from Appledore Island in the Gulf of Maine (location 2; Fig. 1) and Broad Cove in Newfoundland (location 9; Fig. 1) using several methods, including traps of different sizes and nets. These methods allowed us to capture all size classes of adult fish present in these populations; however, large, territorial males in the Gulf of Maine appeared to avoid our sampling gear and thus may be underrepresented in our sample. To age fish, sagittal otoliths (earstones) were removed, mounted on slides and viewed under a microscope. Otolith growth was concentric around a central nucleus and distinct bands were present. When viewed microscopically, layers corresponding to summer periods of active growth appeared as white opaque zones while layers laid down during periods of slow growth (late fall, winter and early spring) appeared as dark bands. Age in years was determined by counting the number of dark bands or annuli. Annulus formation has been experimentally validated (Chiasson unpubl. data).

\section{RESULTS}

\section{Spatial patterns of abundance}

$$
\text { Geographic patterns }
$$

Distinct differences in the abundance of cunner were found between Newfoundland and the Gulf of Maine. Significantly greater numbers of adults were found in Newfoundland than in the Gulf of Maine and this difference was consistent over time (Table 1). For the 2 years of the study combined, the mean density of adults in Newfoundland was ca 3-fold greater than in the Gulf of Maine (Fig. 2).

The difference in recruitment between Newfoundland and the Gulf of Maine was striking (Fig. 2). On more than 375 transects during 3 years at (2 years of
Table 1. Analysis of variance on the densities of adult cunner in Newfoundland versus the Gulf of Maine (region) in 1991 and 1992. Analyses were performed on $\log (x+1)$ transformed data. Significance: $\cdots p<0.001$

\begin{tabular}{|lrrrr|}
\hline Source & SS & df & MS & \multicolumn{1}{c|}{$F$} \\
\hline Year & 2.414 & 1 & 2.414 & 1.988 \\
Region & 30.965 & 1 & 30.965 & $25.507 \cdots$ \\
Year $\times$ Region & 0.142 & 1 & 0.142 & 0.117 \\
Error & 458.970 & 378 & 1.214 & \\
\hline
\end{tabular}

the study plus additional censuses in 1993) 12 sites a total of 3 recruits were observed at only 1 site in Newfoundland. In contrast, recruitment in the Gulf of Maine was higher but temporally variable. In 1991 the average density of recruits was $8.32(1.71 \mathrm{SE})$ per $15 \mathrm{~m}^{2}$ transect, and in 1992 the density of recruits averaged 0.98 (0.24 SE) per $15 \mathrm{~m}^{2}$ transect.

When we examined recruitment to standard habitat units which we knew provided appropriate habitat for newly settled cunner, the pattern of low recruitment in Newfoundland and higher recruitment in the Gulf of Maine was repeated. In the Gulf of Maine, we observed a total of 999 cunner settling to $24 \mathrm{~m}^{2}$ of habitat in 1991, and at the end of the settlement season the number of recruits averaged 10.96 (1.60 SE) fish per $\mathrm{m}^{2}$. We saw no settlers and no recruits on our SHUs in Newfoundland. Thorough searches of all surrounding habitat also yielded no settlers or recruits.

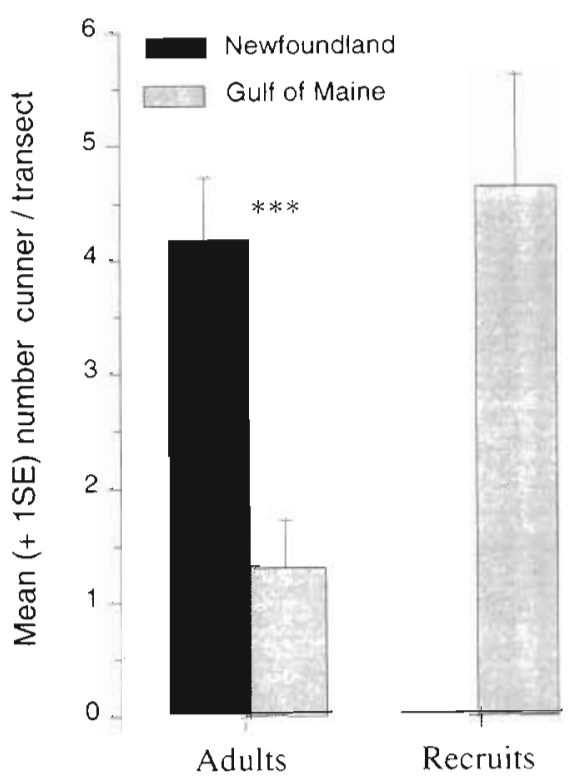

Fig. 2. Tautogolabrus adspersus. Mean number of adult and newly recuited cunner on $15 \times 1 \mathrm{~m}$ transects in the Gulf of Maine and Newfoundland. ' $p<0.001$. See Table 1 for statistical details. Mean number of recruits observed in Newfoundland was 0.008 fish per $15 \mathrm{~m}^{2}$ transect 
Patterns within geographic regions

Adults. In the Gulf of Maine, variation in adult abundance was most pronounced at the scale of site rather than location (Fig. 3, Table 2). Examination of the degree of association $\left(\rho_{1}\right)$ between location or site and adult density, however, revealed that the site scale $\left(\rho_{\mathrm{I}}=\right.$ $0.14)$ and the location scale $\left(\rho_{1}=0.13\right)$ were about equal in their ability to explain variability in adult abundances. Differences among sites were not consistent between years as evidenced by a significant interaction between site and year (Table 2). In 1991, site Nubble 2 had more than 3 times the average density of adults than the other 3 sites where fish were present (Fig. 3). However, in 1992, of the sites where adults were present, site Nubble 2 had the lowest mean density (Fig. 3). Despite an absence of adults in 1991, Shoals 1 had the highest average density of adults in 1992 with ca 3 times the density of other sites.

In Newfoundland, variation in adult abundance was evident at both location and site scales (Fig. 3, Table 2).

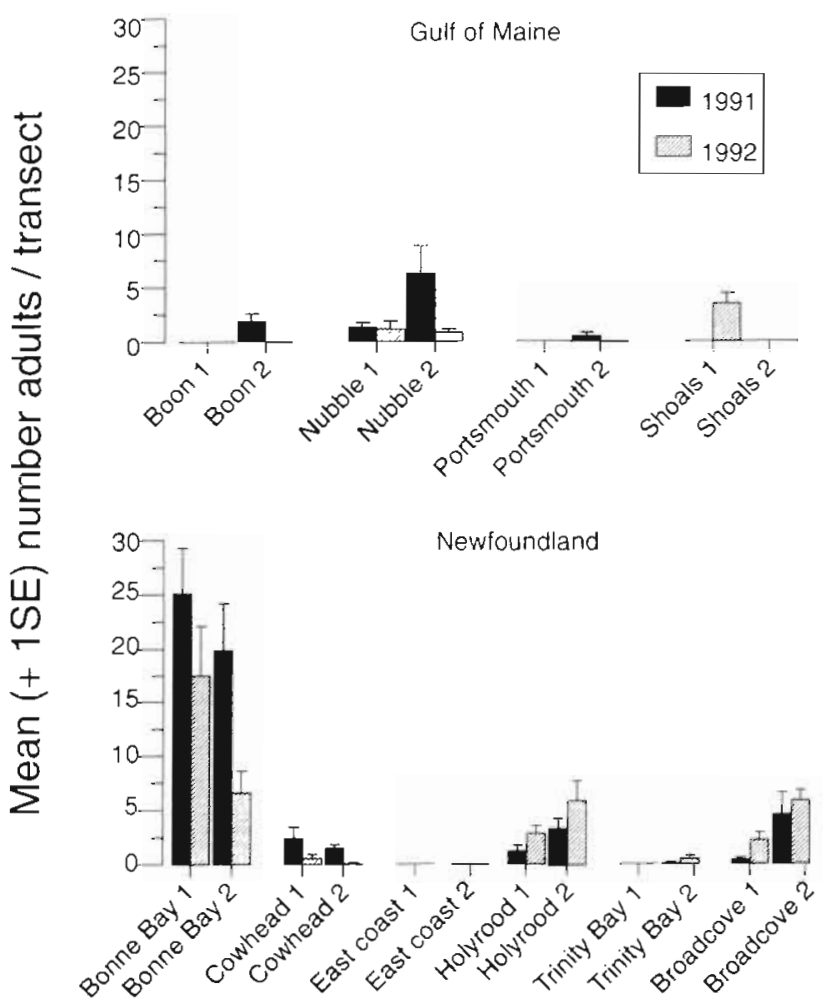

Fig. 3. Tautogolabrus adspersus. Mean number of adult cunner on $15 \times 1 \mathrm{~m}$ transects in the Gulf of Maine and Newfoundland for sites (e.g. Boon 1 and Boon 2) nested within locations (e.g. Boon 1 and 2 are together a single location) in 1991 and 1992. ANOVA revealed that variation was significant at the scale of site in the Gulf of Maine, but there was significant variability at both the location and site scales in Newfoundland (see Table 2 for statistical details)
Table 2. Analyses of variance examining adult densities in 1991 and 1992 at different locations and sites in the Gulf of Maine and Newfoundland. Data were log transformed prior to analysis. Significance: $" p<0.01, \cdots p<0.001$

\begin{tabular}{lrrrr} 
Source & \multicolumn{1}{c}{ SS } & df & MS & $F$ \\
\cline { 1 - 2 } Gulf of Maine & & & & \\
Year & 0.372 & 1 & 0.372 & 0.204 \\
Location & 6.391 & 3 & 2.130 & 1.776 \\
Site(Location) & 4.794 & 4 & 1.199 & $4.594 \cdots$ \\
Year $\times$ Location & 5.464 & 3 & 1.821 & 1.429 \\
Year $\times$ Site(Location) & 5.097 & 4 & 1.274 & $4.881 \cdots$ \\
Error & 35.505 & 136 & 0.261 & \\
& & & & \\
Newfoundland & & & & \\
Year & 1.196 & 1 & 1.196 & 0.257 \\
Location & 218.331 & 5 & 43.666 & $12.079 \cdots$ \\
Site(Location) & 21.689 & 6 & 3.615 & $5.562 \cdots$ \\
Year $\times$ Location & 23.235 & 5 & 4.647 & $22.449 \cdots$ \\
Year $\times$ Site(Location) & 1.241 & 6 & 0.207 & 0.318 \\
Error & 133.948 & 206 & 0.65 & \\
& & & & \\
\hline
\end{tabular}

However, far more variability was explained at the location scale $\left(\rho_{l}=0.61\right)$ than at the site scale $\left(\rho_{l}=0.10\right)$. The location scale differences were largely due to a single location, Bonne Bay. During both 1991 and 1992. the Bonne Bay sites had much higher densities than any other site, with densities at site Bonne Bay 1 averaging greater than 25 per $15 \mathrm{~m}^{2}$ transect in 1991 and 17 in 1992. No adults were observed at the East Coast location, and other locations generally averaged ca 3 adults per $15 \mathrm{~m}^{2}$ transect (Fig. 3 ). The magnitude of the difference among locations differed between years, producing a significant location $x$ year interaction (Table 2). In particular there was a decline in the density of fish in Bonne Bay, but there were generally higher densities at locations in Broad Cove and Holyrood (Fig. 3).

Recruits. The pattern of significant site-scale variation in the Gulf of Maine was evident for recruits just as

Table 3. Analysis of variance examining recruit densities in 1991 and 1992 at different locations and sites in the Gulf of Maine. Only 3 recruits were observed in Newfoundland in both years of the study; thus, no analysis was performed for this region. Data were $\log$ transformed prior to analysis. Significance: $\cdots p<0.001$

\begin{tabular}{lcrrc|}
\hline Source & SS & df & MS & $F$ \\
\hline Year & 56.439 & 1 & 56.439 & 6.813 \\
Location & 28.273 & 3 & 9.424 & 0.633 \\
Site(Location) & 59.494 & 4 & 14.874 & $26.656 \cdots$ \\
Year $\times$ Location & 24.853 & 3 & 8.284 & 0.597 \\
Year $\times$ Site(Location) & 55.515 & 4 & 13.879 & $24.873 \cdots$ \\
Error & 75.941 & 136 & 0.558 & \\
\hline
\end{tabular}




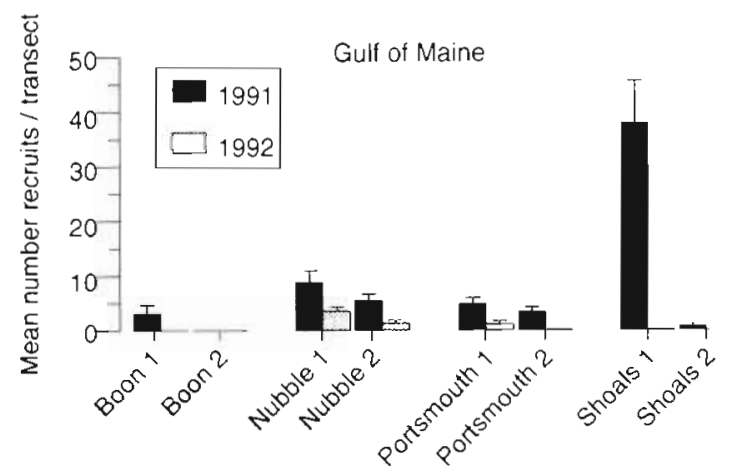

Fig. 4. Tautogolabrus adspersus. Mean number of cunner recruits on $15 \times 1 \mathrm{~m}$ transects in the Gulf of Maine is plotted for sites nested within locations in 1991 and 1992. Designation of the terms site and location is the same as in Fig. 3. ANOVA revealed that variation was pronounced at scale of site (see Table 2 for statistical details). A total of 3 recruits were observed in Newfoundland in 1991-1993, all at Bonne Bay

for adults (Fig. 4, Table 3). Additionally, more variation was explained at the site scale $\left(\rho_{1}=0.30\right)$ than at the location scale $\left(\rho_{\mathrm{I}}=0.09\right)$. The Shoals 1 site averaged $37.8\left(\mathrm{SE}=7.67\right.$ ) recruits per $15 \mathrm{~m}^{2}$ transect in 1991 , and this was more than 4 times the average of any other site. In 1992 recruitment was substantially lower and site Nubble 1 had the highest density with an average of $3.6(\mathrm{SE}=0.65)$ fish per transect. Thus, a significant interaction between site and year was present for recruits as it was for adults

It was not possible to examine patterns of recruitment in Newfoundland since only 3 recruits were seen in 3 years. However, all of the recruits were observed at Bonne Bay, and this happened to be the location with highest adult abundance.

\section{Among-site relationships between habitat structure and abundance}

$$
\text { Algal height }
$$

The relationship between algal height and the abundance of recruits and adults was investigated in 1991 and 1992. Variation among sites in algal height was not significantly associated with variability in the abundances of recruits or adults in either 1991 or 1992 (ANCOVA, $\mathrm{p} \gg 0.05$ ).

\section{Algal cover}

Variation in cover of kelp, branched algae, and foliose algae was associated with variation in the density of fish; however, the nature of the relationship dif- fered among age classes and geographic regions. Only branched seaweeds occurred at our Newfoundland sites, and no relationship between algal cover and abundances of adults was detected. An ANCOVA with year as the main effect and the percentage cover of branched algae as a covariate indicated that neither year $(p=0.20)$ nor branched algae $(p=0.82)$ had a significant effect on adult density. Since few recruits occurred in Newfoundland, we could not examine the effects of algal structure on among-site patterns of recruitment there.

In the Gulf of Maine, algal cover was highly variable and there were significant effects of algal cover on among-site variation in abundance (Table 4). Variation in branched seaweeds appeared to have no influence on the density of adults in the Gulf of Maine (Fig. 5, Table 4). In contrast, adult cunner were associated with sites of high foliose algal cover in 1990 and high cover of kelp in 1991 (Fig. 5, Table 4).

Among-site variation in recruitment in the Gulf of Maine was not explained by the cover of foliose algae or kelp over the entire 3 year period (Fig. 5, Table 4). However, there was a positive association between recruit density and kelp coverage in 1990. Additionally, there was a strong relationship between the cover of branched algae and recruitment in 1990 and 1991 (Fig. 5, Table 4). For example, in 1991, about $80 \%$ of the among-site variation in recruitment could be explained by variability in the coverage of branched algae

Table 4. Multiple analyses of covariance examining the effects of average percent coverage of branching algae, kelps, and foliose algae on the mean densities of adult and newly recruited cunner in 1990-1992. Only sites from the Gulf of Maine are shown here (see text for Newfoundland results). When interaction terms were non-significant at $p>$ 0.25 , they were pooled with the error mean square (Underwood 1981). Transect counts of fish were log transformed and percent cover data were arcsine transformed. Significance: . $p<0.05, \cdots p<0.01, \cdots p<0.001$

\begin{tabular}{|lrrcc|}
\hline Source & SS & df & MS & $F$ \\
\hline Adults & & & & \\
Year & 2.384 & 2 & 1.192 & $3.832^{\circ}$ \\
Branched algae & 0.033 & 1 & 0.033 & 0.106 \\
Kelp & 3.089 & 1 & 3.089 & $9.932^{*}$ \\
Foliose algae & 1.684 & 1 & 1.684 & $5.413^{\circ}$ \\
Error & 4.666 & 15 & 0.311 & \\
& & & & \\
Recruits & & & & \\
Year & 3.753 & 2 & 1.876 & $30.270^{\cdots}$ \\
Branched algae & 2.664 & 1 & 2.664 & $42.9777^{\cdots}$ \\
Kelp & 0.176 & 1 & 0.176 & 2.840 \\
Foliose algae & 0.0002 & 1 & 0.0002 & 0.004 \\
Error & 0.992 & 16 & 0.062 & \\
& & & & \\
\hline
\end{tabular}




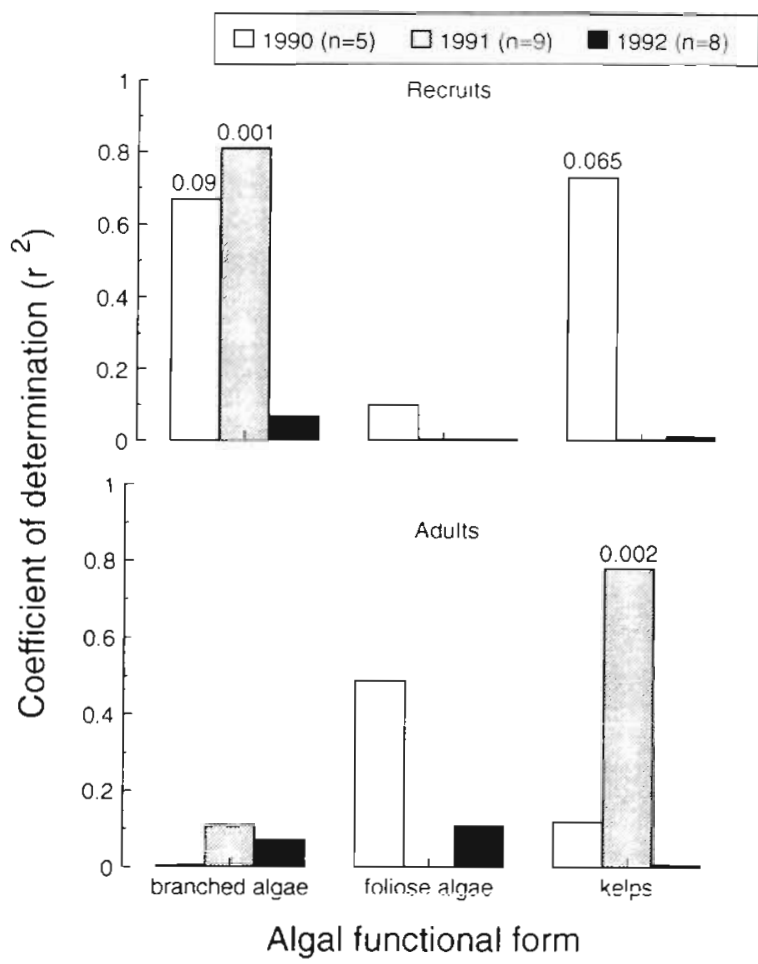

Fig. 5. Multiple analyses of covariance are summarized here by plotting the coefficient of determination $\left(\mathrm{r}^{2}\right)$ from regressions of fish density on algal cover in each year. These values are used only to illustrate the results of the multiple analysis of covariance presented in Table 4 . p-values $<0.10$ from regressions are shown above bars

\section{Age structure of adult populations}

Contrary to an expectation of declining abundance with age due to mortality, $43 \%$ of the 1992 sample from the Broad Cove, Newfoundland population consisted of fish from the 1985 year class (Fig. 6B). Similarly, the age structure of another collection of adult cunner made in 1984 from this site using the same methods and with assistance from one of us (J. M. Green, data from Gravel 1987 ) is incompatible with the expectation of declining abundance with age (Fig. 6A). The dominant year classes, 1969 and 1971, each comprised about $14 \%$ of the population, and thus represent exceptionally strong year classes since these fish were $>13$ yr old at the time of collection.

In contrast to the Broad Cove, Newfoundland population, the expectation of declining abundance with age was generally met in the Appledore Island, Maine population. The age structure of this population was dominated by 2 yr old fish and each subsequent age class declined in abundance (Fig. 6C). Two year old fish were the youngest fish our collecting methods adequately sampled.

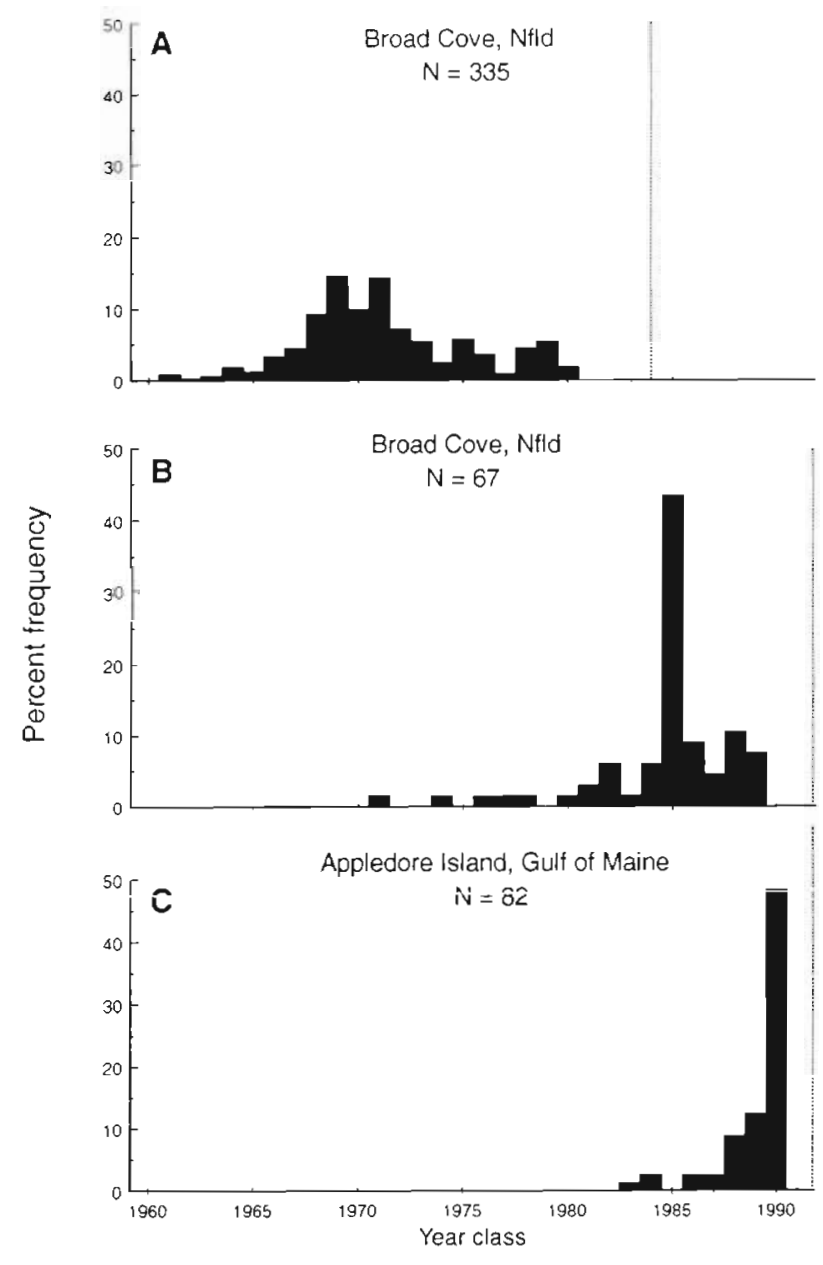

Fig. 6. Tautogolabrus adspersus. The age structure of cunner $>2 \mathrm{yr}$ old is plotted for populations of fish in Broad Cove, Newfoundland and Appledore Island, Maine. Dotted vertical line indicates year of collection. The age structure of the Broad Cove, Newfoundland population is not consistent with the expectation of declining abundance with age, while the Appledore Island, Maine population is consistent with this expectation. Data for (A) were extracted from Gravel (1987)

\section{DISCUSSION}

The scale at which investigations are conducted may influence the patterns that emerge (Dayton \& Tegner 1984, Wiens et al. 1986, Addicott et al. 1987, Menge and Olson 1990, Levin 1992), and no single mechanism is likely to explain patterns exhibited at different spatial scales (Levin 1992). Thus, research on reef fishes should address how well models developed at small spatial scales explain patterns observed at larger scales. Most experimental studies on the ecology of reef fishes have necessarily been conducted at small spatial scales (e.g. Doherty 1983, Jones 1984, 1987. Carr 1989, Forrester 1990. Wellington 1992, Hixon \& Beets 1993, Levin 1993, Tupper \& Boutilier 1995), and 
models predicting the dynamics of populations of reef fishes have emerged largely from these small-scale studies (Doherty 1991, Jones 1991). Those studies that have been conducted at large scales frequently examine small patch reefs over a broad region (Fowler et al. 1992, Doherty \& Fowler 1994) and may simply be examining small-scale processes over large areas.

In this study there were striking differences between geographic regions in the densities of recruits and adult fish. Although far greater densities of adults were observed in Newfoundland, virtually no recruits were observed there. By contrast, in the Gulf of Maine, we observed fewer adults, but high densities of recruits. These regional differences were consistent over time, and this consistency suggests that factors that function at large scales, such as oceanographic processes, may be responsible for the observed pattern. Similarly, the pattern of distribution of fish recruits among geographic regions along the Great Barrier Reef, Australia (Doherty 1987, Fowler et al. 1992, Doherty \& Fowler 1994) and southern California, USA (Cowen 1985) appears to have persisted for several years and is thought to be the result of large-scale oceanographic processes. However, because we were able to sample only a limited number of sites in both the Gulf of Maine and Newfoundland, it is difficult to determine whether the differences we observed are truly 'geographic' in nature or whether similar patterns might emerge between sets of sites separated by hundreds of kilometers within the Gulf of Maine or Newfoundland. Furthermore, the available habitats in the Gulf of Maine and Newfoundland are consistently different, with Gulf of Maine sites having far more macroalgal cover. Thus, it was impossible to hold habitat constant as we increased the spatial extent of our sampling. Nonetheless, the results of our small-scale experiment in which we provided the same recruitment habitat in both regions and still observed high recruitment in the Gulf of Maine and no recruitment in Newfoundland is concordant with our findings at larger scales. Thus, the lack of recruitment in Newfoundland may not be the result of an absence of appropriate recruitment habitat.

The scale at which we detected variation in abundances of fish varied between Newfoundland and the Gulf of Maine. In general, variability in fish density occurred at a smaller scale in the Gulf of Maine than in Newfoundland. In both regions, there were significant changes in the magnitude of among-site differences among years. Variability in patterns of abundance of fish are the result of interactions between the supply of larvae competent to settle, the response of settling larvae to habitat characteristics at a site, and the survivorship of individuals after settlement (Jones 1991).
Changes among years in the relative abundances of fish among cohorts requires that: (1) interannual variability in larval supply is reflected as variability in subsequent age classes; (2) changes in predator or resource abundance alter the probability of a settling larva surviving to different age classes; and/or (3) changes in the habitat of sites or locations make them more or less attractive to settling fish in different years. Below, we discuss the evidence for these possibilities from this study, first considering the significance of pre-settlement processes followed by a discussion of post-settlement processes.

\section{Is variation in the abundance of cunner the result of processes occurring prior to settlement?}

In the Gulf of Maine, variability in the densities of both recruits and adults was consistently most pronounced at the site scale $(10$ to $1000 \mathrm{~m})$; however, variability in the abundance of pre-settlement cunner consistently occurs at the location scale (ca $10 \mathrm{~km}$ ) (Levin 1996). Moreover, the average density of pre-settlement fish at the Isles of Shoals location in 1991 was 2 orders of magnitude lower than at the Portsmouth location (Levin 1996), yet we did not detect a similar pattern for older fish. In fact, average densities of recruits in 1991 were actually greater at the Isles of Shoals than in Portsmouth. This pattern is opposite that expected if larval supply was the primary determinant of population size. At present, there are too few data to unequivocally conclude that pre-settlement processes do not determine population size of cunner; however, spatial patterns presented here are not consistent with what is presently known about the larval distribution of cunner.

The situation in Newfoundland is clearly very different from that of the Gulf of Maine. Despite higher numbers of adults in Newfoundland than in the Gulf of Maine, in Newfoundland we observed only 3 recruits in $3 \mathrm{yr}$. In addition, the age structure of the cunner population in Broad Cove, Newfoundland is dominated by a few widely spaced strong year classes. Our 1992 sample of this population suggests that there had not been a substantial recruitment pulse in $7 \mathrm{yr}$. The alternative explanation that post-settlement mortality was unusually low in these years seems unlikely. Abiotic factors such as temperature, salinity and wind speed or direction were not unusual in the years of strong age classes (Canadian Department of Fisheries and Oceans unpubl. data), and it seems improbable that large variability in predator densities are responsible for the observed pattern.

Although a cautious interpretation of these data is required, it seems possible that episodic recruitment 
events may have been responsible for much of the variation we see in cunner populations in Newfoundland. Newfoundland is at the northern edge of the range of cunner, and recruitment of fishes appears to be more variable at the edges of their range (Cowen 1985, Winemiller \& Rose 1992). Recruitment to populations of other North Atlantic fishes such as cod Gadus morhua, haddock Melanogrammus aeglefinus and herring Clupea harengus is also more variable at the northern limit of these species ranges (Myers 1991). The location-scale variation we observed in Newfoundland is consistent with the idea that pulses of presettlement fish are significant in producing patterns of abundance. We do not yet know how spatially or temporally variable these pulses are, nor do we know the extent that these pulses are modified in different locations or sites.

\section{Is variation in abundance of cunner the result of post-settlement processes?}

Patterns of cunner abundance in the Gulf of Maine were significantly affected by the biogenic structure of the habitat in this study as well as in other studies (Levin 1991, 1993, 1994a, b, Tupper \& Boutilier 1995). Two alternative explanations of this pattern seem plausible. First, it is possible that fish select specific habitats at settlement. The use of specific microhabitats by reef fishes has been demonstrated both on tropical (Sale et al. 1984, Eckert 1985, Sweatman 1985, Booth 1992, Wellington 1992, Tolimieri 1995) and temperate reefs (Carr 1991, 1994, Levin 1991, 1993). Moreover, larger scale associations of reef fish with particular habitats are common (Choat \& Ayling 1987, Jones 1988, Ebeling \& Hixon 1991, Sale 1991).

However, small-scale patterns of abundance created by differential habitat use are not necessarily good predictors of larger scale patterns (Tolimieri 1995). For example, Levin (1991) found that newly settled cunner were associated with microhabitats dominated by branched and foliose algae. In a comparison of 2 sites in the Gulf of Maine separated by ca $100 \mathrm{~m}$, he found that the site with far lower algal coverage had 3 times the density of recruits than the site with higher coverage. However, censuses conducted over the next 2 yr showed that this pattern of recruitment was subsequently reversed such that more juveniles and adults were found in the site with higher algal cover (Levin 1993). Consequently, in this example, habitat selection per se did not produce the observed patterns of juvenile and adult abundance. Rather, it appears that a second mechanism, differential mortality in habitats of different patch structure, produced abundance patterns of older fish (Levin 1993, 1994a). It should be noted, however, that both sites used by Levin in his comparison had relatively high cover of erect macroalgae $(>30 \%)$. Certainly, if sites have extremely low levels of plant cover, broad-scale selection of habitats by settling fish should be more important (e.g Bell \& Westoby 1986). Moreover, in some fish species there appears to be a threshold response to algal cover, such that, below some level, increasing algal cover does not result in increases in recruit density (Anderson 1994, Levin \& Hay 1996). For example, Anderson (1994) found that kelp perch Brachyistius frenatus on reefs off the California coast did not increase in abundance as cover of the canopy of the giant kelp Macrocystis pyrifera increased from 0 to $45 \%$ cover. However, as $M$. pyrifera increased above $45 \%$ cover, there was a dramatic increase in the density of kelp perch.

Further work is clearly needed to fully understand the mechanisms producing the large-scale association of cunner recruits with seaweeds in the Gulf of Maine sites. For example, the correlative approach of this study does not allow separation of losses due to migration versus mortality. This is particularly a problem. with adults since they are much more mobile than recruits or juveniles and are less restricted to algal structure than younger fish (Pottle \& Green 1979, Levin 1993). Despite tagging studies that show adult fish have very restricted movements (Pottle \& Green 1979. Bradbury et al. 1995), if the propensity of fish to move varies among sites or years, then this could change the interpretation of our results. In addition, the role of food supply was not investigated in this study. Recent work suggests that variability in food supply among algal patches influences recruitment variability of cunner (Levin 1994b), and that cunner recruits show density-dependent growth (Tupper \& Boutilier 1995).

Our data for recruitment to Newfoundland populations of cunner are sparse, and thus we can draw only limited conclusions about the importance of post-settlement processes in this region. Adult mortality or movement, however, may be of greater importance in Newfoundland than in the Gulf of Maine. Cunner enter a state of torpor at temperatures below $5^{\circ} \mathrm{C}$ and overwinter in rock crevices within their home range (Green \& Farwell 1971). If the size of overwintering shelters is small, larger adults may not survive the winter (J. M. Green pers. obs.). Moreover, large numbers of adult cunner ( $>2000$ ) have been killed following winter storms in which ice crystals contacted overwintering fish as a result of strong wave action (Green 1974). Thus, at least at single locations, adult mortality may contribute to fluctuations in the size of local populations, particularly since replenishment of the population via larval recruitment appears to be rare and episodic. 


\section{The generality of population models for reef fishes}

Variable replenishment of populations is characteristic of both temperate (Sissenwine 1984, Cowen 1985, Jones 1988) and tropical (Doherty \& Williams 1988, Doherty 1991) reef-fish populations. The process of settlement is a major event in the life history of such populations, and it is not surprising that much attention has focused on events occurring at or near the time of settlement. The paradigm that initially emerged from these studies is that many populations of reef fishes are generally undersaturated as a result of persistently low rates of settlement resulting from a shortage of larvae (Doherty \& Williams 1988). Variability in the rate of settlement was thought to be greater than that associated with post-settlement mortality. Consequently, the rate of settlement was thought to be the leading determinant of subsequent population size.

This paradigm has been modified in favor of an approach that asks questions concerning the relative contribution of variations in settlement and post-settlement loss (Doherty 1991, Hixon 1991, Jones 1991). Answers to such questions, however, have varied among species (e.g. Victor 1986, Forrester 1990, Connell \& Jones 1991, Wellington 1992, Hixon \& Beets 1993, Levin 1994a), and with the scale of investigation (Fowler et al. 1992). Consequently, we must consider the generality of models predicting the dynamics or sizes of population of reef fishes. Can the paradigm established largely in tropical systems be extrapolated to temperate or Arctic zones? Or are we faced with the impracticable, ineffectual task of creating species or geographically specific models?

It is evident that models that are based solely on rates of settlement are too simple to adequately predict the dynamics or sizes of fish populations (Warner \& Hughes 1988, Jones 1991). Models that include variable rates of both settlement and post-settlement loss are clearly necessary (Warner \& Hughes 1988, Hixon 1991, Jones 1991). Recent multi-factor experiments have directed more attention to processes occurring after settlement (Jones 1987, 1990, Forrester 1990, Connell \& Jones 1991, Wellington 1992, Hixon \& Beets 1993, Carr 1994). These studies are the first step towards a more comprehensive understanding of population dynamics of fishes, and future work that simultaneously examines settlement and post-settlement loss should be encouraged. Thus, generalizations concerning the dynamics of fish populations must await further descriptive and experimental studies that investigate both pre- and post-settlement processes. Moreover, studies of single species over a range of spatial or temporal scales are rare, and evidence in this study and elsewhere suggests that meaningful models of population dynamics should address processes occurring at multiple scales (Levin 1992).
Acknowledgements. We thank the many people who offered advice on this project, especially Peter Sale, T P. Good, G. E. Forrester, D. Carlon and R. R. Warner. T Anderson, S. D. Gaines, L. G. Harris, M. E. Hay, A. C. Mathieson, P. F. Sale and R. R. Warner provided many helpful comments on the manuscript. Thanks also to the many divers who helped us, especially D. Carlon, T. P. Good, and L. Neveau who braved the frigid waters of Newfoundland just for fun. This research was supported by National Science Foundation Grant OCE9102027 to P. F. Sale and P.S.L., National Geographic Society Grant 4625-91 to P. F. Sale and P.S.L., and an NSERC operating grant to J.M.G. Supplemental support was proved by NSF Grant DEB-9610353 to P.S.L. and J. A. Coyer

\section{LITERATURE CITED}

Addicott JF, Aho JM, Antolin MF, Padilla DK, Richardson JS, Soluk DA (1987) Ecological neighborhoods: scaling environmental patterns. Oikos 49:340-346

Anderson TW (1994) Role of macroalgal structure in the distribution and abundance of a temperate reef fish Mar Ecol Prog Ser 113:279-290

Andrewartha HG, Birch LC (1954) The distribution and abundance of animals. Chicago University Press, Chicago

Antonovics J. Levin DA (1980) The ecological and genetic consequences of density-dependent regulation in plants. Annu Rev Ecol Syst 11:411-452

Auster PJ (1989) Species profiles: life histories and environmental coastal fishes and invertebrates (North Atlantic and Mid Atlantic) - tautog and cunner US Fish Wildl Serv Biol Rep 82(11.105) (1989) US Army Corps of Engineers, TR EL-82-4

Bell JD, Westoby $M$ (1986) Abundance of macrofauna in dense seagrass is due to habitat preference, not predation. Oecologia 68:205-209

Bigelow HB, Schroeder SC (1953) Fishes of the Gulf of Maine. Fish Bull Fish Wildl Serv 53. US Government Printing Office, Washington, DC

Booth DJ (1992) Larval settlement patterns and preferences by damselfish Dascyllus albisella Gill. J Exp Mar Biol Ecol 155:85-104

Bradbury C, Green JM, Bruce-Lockhart M (1995) Home ranges of female cunner, Tautogolabrus adspersus (Labridae) as determined by ultrasonic telemetry. Can J Zool 73 : $1268-1279$

Carr MH (1989) Effects of macroalgal assemblages on the recruitment of temperate zone reef fishes. J Exp Mar Biol Ecol 126:59-76

Carr MH (1991) Patterns, mechanisms, and consequences of recruitment of a temperate marine reef fish. PhD dissertation, University of California, Santa Barbara

Carr MH (1994) Effects of macroalgal dynamics on secruitment of a temperate reef fish. Ecology 75:1320-1333

Carr MH, Hixon MA (1995) Predation effects on early postsettlement survivorship of coral-reef fishes. Mar Ecol Prog Ser 124:31-42

Choat JH, Ayling AM (1987) The relationship between habitat structure and fish faunas on New Zealand reefs. J Exp Mar Biol Ecol 110:257-284

Connell JH (1985) The consequences of variation in initial vs. post-settlement mortality in rocky intertidal communities. J Exp Mar Biol Ecol 93:11-45

Connell S, Jones GP (1991) The influence of habitat complexity on postrecruitment processes in a temperate reef fish population. J Exp Mar Biol Ecol 151:271-294

Cowen RK (1985) Large scale patterns of recruitment by the 
labrid, Semicossyphus pulcher causes and implications. J Mar Res 43:719-742

Dayton PK. Tegner MJ (1984) The importance of scale in community ecology: a kelp forest example with terrestrial analogs. In: Price PW, Slobodchikoff CN, Gaud WS (eds) A new ecology: novel approaches to interactive systems. John Wiley and Sons, New York, p 457-482

Dew CA (1976) A contribution to the life history of cunner, Tautogolabrus adspersus, in Fishers Island Sound, Connecticut. Chesapeake Sci 17:101-113

Dodd DH, Schultz RF Jr (1975) Computational procedures for estimating magnitude of effect for some analysis of variance designs. Psychol Bull 79:391-395

Doherty PJ (1981) Coral reef fishes: recruitment limited assemblages? Proc 4th Int Coral Reef Symp (Manila) 2: $465-470$

Doherty PJ (1983) Tropical territorial damselfishes: is density limited by aggression or recruitment? Ecology 64:176-190

Doherty PJ (1987) The replenishment of populations of coral reef fishes, recruitment surveys, and the problems of variability manifest on multiple scales. Bull Mar Sci 41: $411-422$

Doherty PJ (1991) Spatial and temporal patterns in recruitment. In: Sale PF (ed) The ecology of fish on coral reefs. Academic Press, San Diego, p 261-293

Doherty PJ, Fowler T (1994) An empirical test of recruitment limitation in a coral reef fish. Science 263:935-939

Doherty PJ, Williams DMcB (1988) The replenishment of coral reef fish populations. Oceanogr Mar Biol Annu Rev 26: $487-551$

Ebeling AW. Hixon MA (1991) Tropical and temperate reef fishes: comparison of community structures. In: Sale PF (ed) The ecology of fish on coral reefs. Academic Press, San Diego, p 509-563

Eckert GJ (1985) Settlement of coral reef fishes to different natural substrata and at different depths. Proc 5th Int Coral Reef Symp 5:385-390

Errington PL (1946) Predation and vertebrate populations. Q Rev Biol 21:144-177

Forrester G (1990) Factors influencing the juvenile demography of a coral reef fish. Ecology 71:1666-1681

Fowler AJ, Doherty PJ, Williams DMcB (1992) Multi-scale analysis of recruitment of a coral reef fish on the Great Barrier Reef. Mar Ecol Prog Ser 82:131-141

Gaines SD, Bertness MD (1992) Dispersal of juveniles and variable recruitment in a sessile marine species. Nature 360:579-580

Gleason TR, Recksiek CW (1990) Preliminary field verification of daily growth increments in the lapillar otoliths of juvenile cunner. Am Fish Soc Symp 7:562-565

Gravel CM (1987) Alternative reproductive tactics and growth of male cunners Tautogolabrus adspersus in Newfoundland. Masters thesis, Memorial University of Newfoundland, St Johns

Green JM (1974) A localized mass winter kill of cunners in Newfoundland. Can Field Nat 88:1

Green JM (1975) Restricted movements and homing of cunner, Tautogolabrus adsperus (Walbaum) (Pisces: Labridae). Can J Zool 53:1427-1431

Green JM, Farwell M (1971) Winter habits of the cunner, Tautogolabrus adspersus (Walbaum, 1972), in Newfoundland. Can J Zool 49:1497-1499

Hixon MA (1991) Predation as a process structuring coral-reef fish communities. In: Sale PF (ed) The ecology of fish on coral reefs. Academic Press, San Diego, p 475-508

Hixon MA, Beets JP (1989) Shelter characteristics and Caribbean fish assemblages: experiments with artificial reefs
Bull Mar Sci 44:666-680

Hixon MA, Beets JP (1993) Predation, prey refuges and the structure of coral-reef assemblages. Ecol Monogr 63: $77-101$

Jones GP (1984) Population ecology of the temperate reef fish Pseudolabrus celidotus Bloch \& Schneider (Pisces:labridae) I. Factors influencing recruitment. J Exp Mar Biol Ecol 75:257-276

Jones GP (1986) Food availability affects growth in a coral reef fish. Oecologia 70:136-139

Jones GP (1987) Competitive interactions among adults and juveniles in a coral reef fish. Ecology $68: 1534-1547$

Jones GP (1988) Ecology of rocky reef fish of north-eastern New Zealand: a review. NZ J Mar Freshwat Res 22: $445-462$

Jones GP (1990) The importance of recruitment to the dynamics of a coral reef fish population. Ecology 71:1691-1698

Jones GP (1991) Postrecruitment processes in the ecology of coral reef fish populations: a multifactorial perspective. In Sale PF (ed) The ecology of fish on coral reefs. Academic Press, San Diego, p 294-330

Lack D (1954) The natural regulation of animal numbers. Oxford University Press, London

Levin PS (1991) Effects of microhabitat on recruitment variation in a temperate reef fish. Mar Ecol Prog Ser 75 $183-189$

Levin PS (1993) Habitat structure, consperifir presence and spatial variation in the recruitment of a temperate reef fish. Oecologia 94:176-185

Levin PS (1994a) Fine-scale recruitment variation in a temperate demersal fish: the importance of settlement versus post-settlement processes. Oecologia 97:124-133

Levin PS (1994b) Small-scale recruitment variation in a temperate fish: the roles of macrophytes and food supply. Environ Biol Fishes 40:271-281

Levin PS (1996) Recruitment in a temperate reef fish: does larval supply matter? Limnol Oceanogr 41:672-679

Levin PS, Hay ME (1996) Responses of temperate reef fishes to alterations in algal structure and species composition. Mar Ecol Prog Ser 134:37-47

Levin SA (1992) The problem of pattern and scale in ecology. Ecology 73:1943-1967

Lincoln Smith MP (1988) Effects of observer swimming speed on sample counts of temperate rocky reef fish assemblages. Mar Ecol Prog Ser 43:223-231

Mapstone BD, Fowler AJ (1988) Recruitment and the structure of assemblages of fish on coral reefs. Trends Ecol Evol 3:72-77

Menge BA, OIson AM (1990) Role of scale and environmental factors in the regulation of community structure. Trends Ecol Evol 2:52-57

Menge BA, Sutherland JP (1987) Community regulation: variation in disturbance, competition and predation in relation to environmental stress and recruitment. Am Nat 130: $730-757$

Myers RA (1991) Recruitment variability and range of 3 fish species. NAFO Scientific Council Studies 16:21-24

Nisbet RM, Bence JR (1989) Alternative dynamic regimes for canopy forming kelp: a variant on density vague population regulation. Am Nat 134:377-408

Ojeda FP, Dearborn JH (1990) Diversity, abundance and spatial distribution of fishes and crustaceans in the rocky subtidal zone of the Gulf of Maine. Fish Bull US 88:403-410

Olla B, Bejda AJ, Martin AD (1975) Activity, movements and feeding behavior of the cunner Tautogolabrus adspersus and comparison of food habits with young tautog Tautoga onitis off Long Island, New York. Fish Bull US 73:895-900 
Pottle RA, Green JM (1979) Territorial behavior of the north temperate labrid, Tautogolabrus adspersus. Can J Zool 57: $2337-2347$

Robertson DR (1991) The role of adult biology in the timing of spawning of tropical reef fishes. In: Sale PF (ed) The ecology of fish on coral reefs. Academic Press, San Diego, p 356-386

Roughgarden J (1986) A comparison of food-limited and space-limited animal competition communities. In: Diamond J, Case TJ (eds) Community ecology. Harper and Row, New York, p 492-516

Roughgarden J, Gaines S, Possingham H (1988) Recruitment dynamics in complex life cycles. Science 241:1460-1466

Roughgarden J, Iwasa Y, Baxter C (1985) Demographic theory for an open marine population with space-limited recruitment. Ecology $66: 54-67$

Sale PF (1980) The ecology of fishes on coral reefs. Oceanogr Mar Biol Annu Rev 18:367-421

Sale PF (1991) The assembly of reef fish communities: open non-equilibrial systems. In: Sale PF (ed) The ecology of fish on coral reefs. Academic Press, San Diego, p 564-598

Sale PF, Douglas WA, Doherty PJ (1984) Choice of microhabitats by coral reef fishes at settlement. Coral Reefs 3:91-99

Sissenwine MP (1984) Why do fish populations vary? In: May RM (ed) Exploitation of marine communities. Dahlem Konferenzen, Springer-Verlag, Berlin, p 59-94

Smith CL (1978) Coral reef fish communities: a compromise view. Environ Biol Fishes 3:109-128

Strong DR (1986) Density-vague population change. Trends Ecol Evol 2:39-42

Sweatman HPA (1985) The influence of adults of some coral reef fishes on larval recruitment. Ecol Monogr 55:469-485

Tolimieri N (1995) Effects of microhabitat characteristics on the settlement and recruitment of a coral reef fish at two spatial scales. Oecologia 102:52-63

Tupper M, Boutilier RG (1995) Effects of conspecific density on settlement, growth and post-settlement survival of a temperate reef fish. J Exp Mar Biol Ecol 191:209-222

Editorial responsibility: Kenneth Heck (Contributing Editor), Dauphin Island, Alabama, USA
Underwood AJ (1981) Techniques of analysis in experimental marine biology and ecology. Oceanogr Mar Biol Annu Rev 19:513-605

Underwood AJ, Denley EJ (1984) Paradigms, explanations, and generalizations in models for the structure of intertidal communities of rocky shores. In: Strong DR, Simberloff D, Abele LG, Thistle AB (eds) Ecological communities: conceptual issues and the evidence. Princeton University Press, Princeton, NJ, p 151-180

Vermeij GJ (1978) Biogeography and adaptation. Patterns of marine life. Harvard University Press, Cambridge, MA

Victor BC (1983) Recruitment and population dynamics of a coral reef fish. Science 219:419-420

Victor BC (1986) Larval settlement and juvenile mortality in a recruitment-limited coral reef fish population. Ecol Monogr 56:145-160

Warner RR, Chesson PL (1985) Coexistence mediated by recruitment fluctuations: a field guide to the storage effect. Am Nat 125:769-787

Warner RR, Hughes TP (1988) The population dynamics of reef fishes. Proc 6th Int Coral Reef Symp (Townsville, Australia) 1:146-155

Wellington GM (1992) Habitat selection and juvenile persistence of two closely related Caribbean damselfishes. Oecologia 90:500-508

Wiens JA, Addicott JF, Case TJ, Diamond J (1986) Overview: the importance of spatial and temporal scale in ecological investigations. In: Diamond J, Case TJ (eds) Community ecology. Harper and Row, New York, p 145-153

Williams DMCB (1991) Patterns and processes in the distribution of coral reef fishes. In: Sale PF (ed) The ecology of fish on coral reefs. Academic Press, San Diego, p 437-474

Winemiller KO, Rose KA (1992) Patterns of life-history diversification in North American fishes: implications for population regulation. Can J Fish Aquat Sci 49:2196-2218

Winer BJ, Brown DR, Michels KM (1991) Statistical principles in experimental design, 3rd edn. McGraw-Hill, New York

Submitted: December 4, 1996; Accepted: October 24, 1997 Proofs received from author(s): December 22, 1997 